\title{
Brand bravery: Conceptualization, scale development and validation
}

\author{
Jain, K., Jajodia, I., Sharma, P. and Singh, G.
}

Purpose: Brands today operate in a dynamic business environment, which often requires them to take courageous actions, from taking a stand on controversial issues to responding to changing market needs. However, these actions are not merely strategic but also represent a unique aspect of the brands' identity, which includes holding up to their core values and being resilient to social pressure. To better understand this positive virtue current study introduces the concept of brand bravery - a novel brand archetype that emulates the brand's distinct identity. This study aims to conceptualize brand bravery and develop a psychometrically sound scale to measure it and investigate its relationship with positive brand relationship outcomes.

Design / methodology / approach: Two qualitative studies were conducted to identify the dimensions of perceived brand bravery. Three empirical studies develop and validate the proposed measurement scale and confirm the construct's nomological validity by proposing a framework that explains the outcomes of perceived brand bravery.

Findings: Results from multiple studies support a seven-factor second-order reflective scale of perceived brand bravery, with dimensions ABCDEFG (Altruism, Bold, Courageous, Determined, Enduring, Fearless, and Gritty). The construct of brand bravery is found discriminant from other conceptually distinct but related brand attributes. Nomological validity tests further suggest that perceived brand bravery leads to positive consumer-related outcomes such as brand advocacy behaviors, positive attitude and consumer brand identification.

Originality: The study introduces a novel brand attribute that has not been previously discussed beyond social and moral psychology literature. It conceptualizes brand bravery that will strengthen the understanding of this specific brand characteristic and provides a practical scale to measure brand bravery.

Practical Implications: Brand bravery provides a vital roadmap to marketers who have sought to create a leading brand that can stay relevant in times of disruption. The multi-factor scale can help managers track which dimension of the brand bravery scale is more relevant for shaping overall bravery perception.

Keywords: Brand bravery, consumer-brand identification, brand advocacy, scale development, and validation

Paper type: Research Paper 


\section{Introduction}

"Believe in something. Even if it means sacrificing everything."

This iconic slogan is from Nike's most popular yet controversial ad campaigns, featuring Colin Kaepernick - the former NFL quarterback. He is known for initiating protests against racism and social injustice after refusing to stand up for the national anthem during a pre-season NFL game. So, when Nike signed a multiyear deal with the activist athlete, the brand's patriotic fan base did not take it in good stride. The incident led to a performative outrage as people started to burn their Nike shoes and declared a moral boycott to denounce Colin Kaepernick. However, Nike firmly stood its ground and communicated what it believes in, even if it meant offending people.

The much talked about incident galvanized the debate among marketers about whether brands should convey their purpose through advertising. Brands like Nike and PandG are known for communicating their stand on sensitive socio-political issues that sometimes require withstanding the force of consumer power. Academia has discussed consumer's reactions to such brand activism (Abitbol et al. 2018; Mukherjee and Althuizen, 2020) and have shed light on the positive outcomes of corporate social advocacy (Dodd and Supa, 2015; Park and Jiang, 2020), where brands took a definitive stance on divisive issues. Nevertheless, Nike's example is not merely an act of advocacy or a reflection of its creative audacity. It also represents a unique aspect of the brands' identity, which includes holding up to its core values and being resilient to social pressure. However, is that desirable for brands that are typically expected to achieve simple outcomes like consumer satisfaction and loyalty? Despite the backlash following the Kaepernick campaign, Nike saw $31 \%$ boost in online sales and increased store traffic (Edison Trends, 2018). Clearly, consumer's expectations from brands are evolving. Having established that consumers desire to build human like relationship with brands (Fournier, 1998), use them to express their ideal selves (Belk, 1988; Hogg et al., 2000), and prefer brands they perceive to be congruent with their self concept (Aaker 1999; Sirgy, 1982), it will be interesting to know if consumers can look up to brands who are not hesitant to communicate their values and beliefs. More recently, in this vein, many corporations, big and small, have issued statements in solidarity with the "Black Lives Matter" movement in the US. Whether the consumer perceives these brand actions as an act of compulsion or a positive virtue that reflects the brand's identity is worth exploring. 
This question is more important now than ever, as the world is going through a global health emergency. These uncertain times, brought upon us by the global outbreak of novel Coronavirus, have put big corporations under critical observation for their response to this crisis. Some brands rose to the occasion and embraced new paradigms of responsibility, empathy, and agility. Some took bold, short-term actions responding to new marketplace needs. LVMH, for instance, started a production line for manufacturing facemasks and sanitizers (Schultz, 2020). Brands tried to set themselves apart by being most responsive to this crisis and expressing their desire to be useful, serve, and not just sell and make impactful decisions. This global pandemic has called upon brands to actively engage and delve on the importance of their purpose to consumers while they show resilience in thriving in these turbulent times. According to Kapferer (2012), leading brands are guided by personal goals; they have clarity of their identity, which is resistant to change. Having a purpose and being driven by it is a crucial aspect of a brand's identity reflected in the brand's culture, positioning, core values, and personality (Kapferer, 2012; Harris and de Chernatony, 2001; de Chernatony, 2002). Brands like Nike and LVMH represent an emerging breed of such brands that stay true to their core identity and do not conform to the standard norms of brand behavior. To better understand this unique attribute of these brands' personality, the current study introduces "the brave" - a novel brand archetype that emulates the brand's distinct identity.

The oxford dictionary defines bravery as the quality of being courageous. In today's dynamic world, brands are continually confronting situations that often require them to be courageous from taking a stand on controversial issues to responding to changing market needs.

Traditionally, in psychology, being brave has been associated with willingness to make sacrifices (Lord, 1918), concern for others (Oliner, 2003), moral excellence (Walker et al., 2010) redemptive behaviors (Walker and Frimer, 2007), and heroism (Jayawickreme and Di Stefano, 2012; Dunlop and Walker, 2013). However, branding literature has no explicit reference to brave personality, its characteristics, and whether it could attract consumer attention. Some recent studies have discussed actions similar to Nike's Kaepernick campaign under brand activism (Mukherjee and Althuizen, 2020), and corporate social/political advocacy (Frynas et al., 2017; Kim et al., 2019; Hoffmann et al., 2020; Park and Jiang, 2020). Corporate social responsibility (CSR) literature also covers some ground in this context by discussing brands' voluntary activities to fulfill their obligations to various stakeholders, communities, and society (Coombs 
and Holladay, 2011; He and Harris, 2020). However, the authors could not find an apparent consensus among researchers regarding a construct representing these brand activities as a signal of brand identity, and its influence on positive brand-related outcomes.

In this vein, the authors initially offer a conceptualization of brand bravery following the construct definition guidelines recommended in the literature (Goertz, 2006; Mackenzie et al., 2011; Podsakoff et al., 2016). First, a set of possible attributes of bravery are collected by examining existing literature from psychology and branding. Next, two qualitative studies are conducted to validate those attributes and identify new characteristics. Based on these attributes, a preliminary definition of brand bravery is generated following a review by two independent judges (Gilliam and Voss, 2010).

The authors then develop an integrative framework and scale for measuring brand bravery. Next, brand bravery is linked with various favorable brand-related outcomes such as brand advocacy behaviors, attitude, and congruity with the self-concept. The study aims to expand the theoretical understanding of the concept of brand bravery and shed light on its importance for consumers' brand-related attitudes and behaviors and its appeal to consumers' self-identity. This research provides marketers and academics with a practical instrument to evaluate what constitutes brand bravery and identify its strategic importance. The proposed scale can also be used to provide a precise examination of consumer perception of brand bravery and assess consumers' response to the brand's actions. The study's findings can help marketers assess the importance of incorporating brave as part of their identity and fostering positive brand-related outcomes. This study can also help business communication experts to understand how specific brand actions can serve as signals of brave brand identity.

In the upcoming sections, the concept of brand bravery is introduced by drawing insights from psychology literature on bravery, brand identity, and brand personality archetype by Carl Jung. Based on the literature and two qualitative studies, the dimensions of brand bravery are identified. Next, the process of scale development is presented. A series of empirical studies are used to validate the scale of perceived brand bravery. Finally, a conceptual framework is proposed that tests the nomological validity of the scale as well as establish its relationship with positive brand-related outcomes. 


\section{Theoretical background and conceptualization}

While marketers strive to create distinct brand identities, marketing and branding literature has no clear reference of brave bravery, what it means to be brave and what characterizes brave brands. Therefore to conceptualize brand bravery, the authors refer to psychology literature that has investigated personality traits associated with bravery and use grounded theory to identify characteristics associated with brave brands.

Early psychologists defined bravery as a willingness to sacrifice one's life to save others' lives (Lord, 1918). A series of research was then undertaken to seek explanation for such remarkable actions of bravery which led to diverse perspectives. London (1970) observed that brave individuals possess heightened sense of adventurousness and are attached to a role model. Later, Oliner (2003) found brave exemplars exhibiting increased sense of self efficacy and concern for others' welfare. Walker and Frimer (2007) self-efficacy personas are characterized by a heightened degree of motivation and redemptive behaviors. Through a series of qualitative studies, Walker and Hennig (2004) proposed 67 characteristics for the brave type (e.g., heroic, intrepid, faces danger). Walker et al. (2010) also identified personality characteristics associated with moral excellence alongside brave and caring personalities. Later, Dunlop and Walker (2013) drew upon a personality profile of brave exemplars and found that dominance, need for personal growth, and early life elements such as redemptions and early advantages are underlying traits leading to exceptional bravery. In the classification of character strengths and virtues, bravery has been defined as the ability to not being held by difficulties or challenges (Ruch and Proyer, 2015; Martínez-Martí and Ruch, 2017).

Theoretically, some aspects of bravery, as discussed in psychology literature, overlap with the concept of heroism. Extant studies discuss heroism as a commitment to noble causes and the welfare of others and propensity to make sacrifices to achieve their purpose (Franco et al., 2011; Franco and Zimbardo, 2006; Becker and Eagly, 2004). The courage shown by rescuers of the weak (such as Oskar Schindler, who saved over a thousand Jews during the Second World War) has been studied in the context of both bravery and heroism (London, 1970; Jayawickreme and Di Stefano, 2012; Dunlop and Walker, 2013). Bravery, as it happens, has been identified as character strength of heroism (Peterson and Seligman, 2004; Seligman, 2002a, 2011; Jayawickreme and Di Stefano, 2011; Kinsella et al., 2015a, 2017). Due to a lack of precise 
terminology and consistency in conceptual analysis, bravery and heroism have been used interchangeably in academic and public discourse, despite historical and philosophical distinction between the two concepts. Table 1 summarizes the various contexts in which the concept of brave has been referred to and highlights the key characteristics discussed in that context.

\section{Insert Table 1 here-}

The closest reference to brand bravery in the context of marketing and branding literature is brand personality archetype "hero", proposed by Pearson and Mark (2001), who developed Carl Jung's (1938) 12-archetype model to study practices of brand storytelling. They define and identify brands by analyzing brand personality archetypes in their book "The Hero and the Outlaws". Pearson and Mark (2001) describe heroic brand personality as a brand that does not hold back from taking difficult action, which exerts mastery in a way that improves the world. Brands like Nike have been discussed in reference to heroic characteristics, someone who loves challenges (Smith, 2016). Smith (2016) considered brand philanthropy and corporate social responsibility as a natural fit for the hero archetype and mentioned being brave as a sub archetype of the hero. In this vein, it can be argued that that brave brands develop the idea of proving one's worth through courageous actions. Exemplars of brave brands must set themselves apart through their deeds and acts. According to Interbrand Global CEO, Charles Trevail, living with what you believe in is even more important than making money for brands. Earlier Smith and Milligan (2011) discussed examples of brands that were brave in doing business. These brands demonstrated that purpose comes before profit, went beyond customer expectations, and relentlessly differentiated themselves from everyone else by being bold in their thought and execution. Barth and Kemp-Robertson (2018), in their book "The contagious commandments: ten steps to brand bravery" suggested brands to take chances, defy conventions, and stand out from the herd (p.258). Hence, brave brands would possess the courage to intercept the future and not just flow with it. Marketers believe that being "brave" requires moving away from stereotypical marketing norms in communication strategy and at a basic level of creative ideation (Adams, 2018).

Experts have also discussed marketing for social causes as a facet of true brand bravery. PandG's Chief Brand Officer, Marc Pritchard pointed out the importance of being brave for the marketing 
leaders such as the CMOs who should live out the values they embrace and build trust within their teams (Adams, 2018). The executive reported his own experience, where he underplayed his mixed heritage for fear of being judged, as an inspiration for PandG's "The Talk" campaign that examines how black parents discuss racial biases with their kids. Despite the backlash, the brand doubled their PR and ad expenses behind the campaign, a move which they considered as brave.

Considering the above characterization, consumers can perceive a brand to be brave, if it accepts challenges (enduring), thinks of the greater good (altruistic), sticks to its core values (determined), challenge existing norms (bold) and is not afraid to take risks (fearless). However, the fragmented definition of bravery in psychology and its lack of reference in branding and consumer research illustrates that there is no convergence for the definition of bravery in literature, highlighting the need to establish a clear and empirically grounded understanding of brand bravery. To further validate these traits of bravery in the context of brands and identify new dimensions, the authors used an exploratory approach.

\subsection{Study 1: Qualitative study}

Two studies, one using an open-ended elicitation procedure and one focus group were conducted to identify characteristics of brand bravery. Qualitative methods are well suited for developing a theory or defining a new construct (Patton, 2001). In study 1, N=100 university students were asked to write down examples of people they considered brave and why. This was done to ensure that the characteristics identified from literature were consistent with the general perception of bravery. The same respondents were then asked to think of a brand that they considered brave and provide a brief narrative to support their answers (Table 2). In the second study, a focus group (8 participants) was conducted, which lasted for 60 minutes. Informants were asked to discuss questions like "which brand comes to your mind when you think of the word brave?", "what are the essential characteristics that you relate with brave brands?". Data from the two studies were then coded and analyzed using constant comparison to arrange and reduce the coded data. The analysis led to the identification of six themes related to brand bravery that the authors termed as ABCDEF of brand bravery (Altruism, Bold, Confident, Determined, Enduring, and Fearless). 


\section{Altruism}

Altruism emerged as a prominent theme from the qualitative study. Participants reported that they perceived brands contributing to social and environmental causes as brave (table 2). Rising above profit-making and thinking about the benefit of the stakeholders and society requires courage. Participants specifically talked about brands like Lego and Burger King for their movement against plastic usage as brave, as these actions were selfless and motivated by ensuring consumer well being. Skittles was brave for standing up for Queer rights. Luxury brands like Prada and Burberry were perceived as brave for going fur-free to protest against animal cruelty, despite the long association of fur with luxury clothing. This theme also converges with prior literature in psychology that has associated altruism with characteristics of bravery (Becker and Eagly, 2004; Peterson, 2006) as the primary motivation of the brave is to help others by committing to noble causes (Franco et al., 2011; Franco and Zimbardo, 2006).

\section{Bold}

This theme includes brands that were discussed for their defiant marketing strategies and nonconformity to industry stereotypes. In particular, participants used Netflix's example for its atypical decision to stream all episodes of the famous web series House of Cards on its platform that proved to be a turning point for the brand. Some respondents also talked about Coco Chanel for breaking the stereotypes related to women's clothing back in the days when woman fashion revolved around tight clothing and corsets. Both brands chose not to conform to conventional ways of performing business. Prior studies have found that such defiance can be perceived as innovative by consumers (Barone and Jewell, 2013). In consumer psychology, non-conforming behaviors have been associated with positive inferences about status and competence (Bellezza et al., 2014). Smith and Milligan (2011), in their book "Bold: How to be Brave in Business and Win", have discussed brands that stand out of the crowd by challenging industry norms, suggesting that non-conformity can also be perceived as brave.

\section{Confident}


This theme sheds light on a positive characteristic of brands that have confidently admitted to their mistakes and shortcomings. Respondents in the qualitative study opined that acknowledging one's mistakes is an act of bravery and courage as everyone does not have the mettle to do it. When KFC issued an apology for running short on its key ingredient, it won the consumers' hearts through this brave move. A leading Indian e-commerce company Flipkart was able to regain customers' trust after the company's CEO sent a personal apology email to its customers when the platform's "big billion sale" led to vast chaos. Respondents argued that such acts could only be pulled off by brands that are confident of their image. Based on the participant's responses, it can be inferred that accepting one's mistakes reflects the confidence of the brands, which is an integral part of being brave.

\section{Determined}

Another critical characteristic of brand bravery is related to brands' determination towards their core values. When introducing the concept of bravery at the beginning of this study, the authors referred to the famous Colin Kaepernick campaign by Nike. This incident was vastly discussed during the qualitative studies as an ideal illustration of brand bravery. Respondents argued that such acts define what a brand stands for. Similarly, Starbucks employed 10,000 refugees after the immigration ban on middle-east countries by US President Donald Trump, reflecting the brand's determination to reaffirm its identity. This move clearly advocates the brand's stance on an important socio-political issue and signals its image of being liberal and accommodating to all. These acts reflect a unique and "uninhibited" aspect of the brands' identity, which forms an essential characteristic of being perceived as brave (Lee and Cho, 2012).

\section{Enduring}

Referring to brands that made a comeback after suffering setbacks and failure in business, endurance forms a crucial aspect of being brave. Brands like Nokia and Nestle's Maggi (Table2) were mentioned for withstanding crisis situations and showing a strong spirit of sustaining adversities. This constituent trait of bravery has been echoed in VIA classification of six virtues and character strengths (Ruch and Proyer, 2015; Martínez-Martí and Ruch, 2017) (Table 1). Evidently, bravery as been previously associated with attributes of resilience (Hutchinson et al., 2010; Martínez-Martí and Ruch, 2017). This observation can indirectly be linked with the 
findings of Peterson et al. (2006), who relate bravery with life satisfaction following a physical illness. As such, brave brands will not shy away from challenges and confront the tough situation with determination.

\section{Fearless}

Characterized by risk-taking behaviors, the fearless dimension of brave discusses brands that showed courage in entering a new business with no certainty of success. Fearless brands are not scared to innovate (Apple), dare to venture in new business lines (Pantanjali entering an already competitive FMCG market in India), and can be unconventional in doing business (Adidas launching the 'superstar' sneakers from the 80 's). This theme converges with the definition of bravery linked with pro-social risk-takers and heroism in the psychology literature (Levenson, 1990; Martínez-Martí and Ruch2017). Jordan (2005) has also associated bravery with one's capacity to move into a situation despite feeling fear and hesitation. The various illustrations from qualitative study 1 reinforce this aspect of bravery in the context of brands.

\section{Definition}

Five of the themes that emerged from the qualitative study (altruism, bold, determined, enduring, and fearless) converge with existing conceptualization of bravery in prior literature. The new characteristic trait identified from the qualitative study was confident, which is reflected by the brand's strength in accepting its mistakes. A confident brand is sure of its image and the values it portrays and is therefore not afraid to declare its flaws. Based on these themes, it can be argued that brave brands are the ones that are selfless and committed to the overall well being of different stakeholders, are bold and intrepid, confident enough to admit when they falter, determined towards upholding their core values and beliefs, resilient in times of crisis and courageous in taking risks.

\section{Scale development methodology}

Findings from study 1 confirm that brand bravery is a construct with multiple components. Studies 2 to 4 aim to empirically validate these different dimensions of brand bravery and provide evidence for its predictive validity. 


\subsection{Item Generation, content and face validity}

Based on the responses received from qualitative studies, an initial pool of 51 items was created and divided into six dimensions (Strauss and Corbin, 1994) according to the themes identified from the qualitative analysis (ABCDEF: Altruism, Bold, Confident, Determined, Enduring and Fearless). Next, following the process by Yi and Gong (2013), four experts, including two Ph. D. scholars and two marketing professors, evaluated these items by judging their relevance, clarity of wordings, and their representation of the concept of brand bravery (Foroudi et al., 2014). Before evaluating, the experts were provided with the illustrations for each dimension (shortlisted from the illustration from qualitative study 1). First, the authors asked the experts to indicate if the items represented their assigned dimension $(\mathrm{ABCDEF})(1=$ not applicable and $5=$ applicable). They were also asked to rate the level of representation of the generated items for the concept of brave brands ( $1=$ not at all representative and $5=$ clearly representative). This process is widely recommended and used in management research for ensuring the face and content validity of the scale items (Zaichkowsky, 1985; Bearden et al., 1993; Yi and Gong, 2013; Morhart et al., 2015; Odoom et al., 2019). Based on their evaluation, the authors retained all items rated 3 and above in both level of representation for bravery and its specific dimension. Following this process, 31 items were used for scale construction. The scale constituted six subscales with five items each for altruism, bold, enduring, and fearless, four items for determined and seven items for confident (Appendix A).

\subsection{Study 2: Item refinement, dimensionality, and reliability}

With the item pool development, the next step is to examine the scale's psychometric properties and test construct validity (MacKenzie et al., 2011). Thus, a survey, including all 31 items developed to measure perceived brand bravery's underlying dimensions, was conducted. An online questionnaire was circulated among 250 respondents. The questionnaire initially provided the oxford dictionary definition of bravery and then exposed the respondents with some examples of human bravery mentioned by respondents in study 1 (Appendix B).Respondents were then instructed to think of a brand that they will associate with similar bravery characteristics, from any of the examples presented in the questionnaire. The respondents rated that brand on the scale items generated earlier on a five-point Likert scale $(1=$ completely disagree and $5=$ completely agree). After removing incomplete questionnaires, data $(\mathrm{N}=238$, 
Male: 45.8\%, Female: 54.2\%; Mean Age: 29 years) was subjected to principal component analysis (PCA), which indicated seven factors based on eigenvalues. An exploratory factor analysis (EFA) using varimax rotation was conducted. Using an iterative process, items with factor loading less than 0.50 , high cross loadings of more than 0.40 , and low commonalities below 0.30 were eliminated (Hair et al., 2010), leading to a clean 24 items 7 -factors matrix. The examination of the scree plot also indicated the presence of seven factors. All the seven factors had eigenvalues greater than one and explained $57.09 \%$ of the total variance. The Kaiser-Meyer Olkin (KMO) value of 0.818 and a significant chi-square value for Bartlett's test of sphericity $\left(\chi^{2}\right.$ $=1115.02)$ indicated that factor analysis was appropriate for the data.

The most commonly named brands for bravery in the survey were Apple, Nike, McDonald's, KFC, Nokia, Adidas, Maggi, Amul, Skittles, Mahindra, Tata, and Tesla. Some of the items, initially categorized in a different sub-factor among ABCDEF (in study 2), did not load on the same factor and were therefore included in their new factor. Since two items heavily loaded separately as the new 7th factor, the authors renamed the initially identified dimensions into seven sub-factors (ABCDEFG).Based on the results of the EFA, a seven dimension brave brand scale was conceptualized. For the purpose of maintaining the initial nomenclature, the dimension confident was renamed as gritty, and courageous was introduced as the new dimension, thus leading to the acronym ABCDEFG: Altruism, Bold, Courageous, Determined, Enduring, Fearless and Gritty. Table 3 presents the final list of items retained for confirmatory factor analysis.

-Insert table 3 here

\subsubsection{Confirmatory Factor Analysis}

Keeping in mind the themes identified in qualitative study (study 1), confirmatory factor analysis was performed, using a reflective model at each level. The characteristics of bravery derived earlier appear more like the manifestations of brand bravery rather than being formative measures. CFA confirmed a final model with brand bravery as second-order reflective construct consisting of 7 first-order factors (ABCDEFG) (Figure 1). 
The results of the CFA for higher-order brand bravery reflective construct reported acceptable measurement model fit of the data $\left(\chi^{2}=309.68, \chi^{2} / \mathrm{df}=1.259, \mathrm{CFI}=0.929\right.$, RMSEA $=0.037$, SRMR $=0.059)(\mathrm{Hu}$ and Bentler, 1999). Convergent validity of the scale was examined based on factor loadings, average variance explained (AVE), and composite reliability (CR). As indicated in figure 1 and table 3 , the factor loading of the construct perceived brand bravery on each of its seven dimensions was above the recommended value of 0.5 (Hair et al., 2006; Byrne, 2010). The AVE of the scale was 0.579 , which is above the desired value of 0.5 , and composite reliability was observed to be 0.904 (Fornell and Larcker, 1981; Hair et al., 2010; Hu and Bentler, 1999). Additionally, a measure of internal consistency, Cronbach's alpha was reported as 0.859 . Together, these values indicate that no further elimination of items is necessary and supports high construct reliability and validity of the proposed 24 -items brave brand scale with seven dimensions.

\subsection{Study 3: Discriminant Validity}

Brand bravery is a perceived attribute of the brand. It, therefore, should be conceptually different from other attributes such as the dimensions of perceived brand authenticity (Morhart et al., 2015), in particular, brand integrity and brand credibility; and also from brand trustworthiness (Erdem and Swait, 2004). The integrity of the brand is reflected by the values it communicates and the perceived intentionality behind it, while the credibility of the brand indicates its willingness to stick to its promises (Morhart et al., 2015). Similarly, brand trustworthiness indicates the extent to which brands fulfill their commitments (Erdem and Swait, 2004). These constructs were chosen as they all are perceived attributes of the brand similar to brand bravery and indicate desirable brand characteristics, leading to positive outcomes. There is also a theoretical overlap between these constructs and some bravery characteristics such as altruism, determined, and courageous (as defined in table 2). Therefore, the latent construct of higherorder brand bravery must indicate discriminant validity from these constructs. To establish discriminant validity from conceptually different but related constructs, a survey using the same method as employed in study 2 , was conducted. A total of $\mathrm{N}=300$ responses (38.3\% females and $61.67 \%$ males, mean age 31.2 years), were collected. After eliminating incomplete responses, 280 responses were used for the analysis. Four items to measure brand integrity and three items for credibility were adopted from Morhart et al., 2015); 5 items to measure brand 
trustworthiness were taken from the work of Erdem and Swait (2004). All the items were measured on a five-point Likert scale.

Following the procedure by Wang et al. (2019), the chi-square difference test was used to assess discriminant validity. Three sets of CFA were performed. In each set, the pair of two constructs (e.g., brand bravery and integrity) was first tested as a single-factor model and then as a twofactor model. The model fit comparison of the two models in each set is represented in table 4. In every set, the CFA models with two factors indicated better model fit parameters reflecting that the two constructs are distinct (Anderson and Gerbing, 1988). The improvement in $\chi^{2}$ from the one-factor model to the two-factor model indicates that the concept of brand bravery is distinct from the brand trustworthiness and the two brand authenticity dimensions - integrity and credibility.

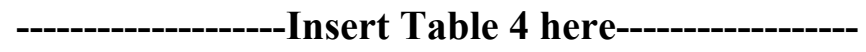

In addition to the chi-square difference test, discriminant validity was also established using Fornell-Larcker criterion (Table 5), according to which the squared correlations $\left(r^{2}\right)$ between constructs should be less than the AVE of the construct (Fornell and Larcker, 1981).

\section{------------Insert table 5 here-------------}

The scale development process is summarized in Figure 2

-Insert Figure 2 here-

\section{Nomological Validity}

To test the brand bravery scale's nomological validity, the relationship of brand bravery with other constructs was tested. Considering that brand bravery is a desirable attribute of the brand, it is expected to lead to positive outcomes like resistance to negative information, brand advocacy, brand attitude, and consumer brand identification. Additionally, self-brand congruity is posited to mediate the relationship between perceived brand bravery, brand attitude, and consumer brand identification.

\subsection{Outcomes of perceived brand bravery: Advocacy behavior, positive attitude and self-brand identification (SBI)}


Bravery is a strong persona to portray. Going by definitions of bravery from psychology literature, it can be asserted that being brave would mean commanding respect and admiration. Due to the higher level of perceived goodwill attached to the concept of bravery, it is posited that brand bravery can create a buffering effect on the consumers, making them resistant to negative information against the brand. In times of vast information influx, polarized opinions, and social networking platforms that encourage freedom of voice, information diffusion is not always within the brands' control. Therefore, branding strategists emphasize the need to have a strong and favorable brand image. A brand's CSR image has been earlier found to influence resistance to negative information (Eisingeric et al., 2011) and, more recently, on brand advocacy (Xie et al., 2019). Brand identity research also supports the immunization effect of brand identity fusion against transgressions (Lin and Sung, 2014). Consumers often engage in pro-social behaviors to support the benefactors (McCullough et al., 2008) and doer of good deeds (Algoe and Haidt, 2009). Since bravery is associated with altruistic and courageous acts, consumers' emotional and evaluative reactions will drive them to advocate the brands they perceive as brave. This positive assessment of the brand's actions can also lead to a favorable attitude towards the brand. Therefore, it is expected that perceived brand bravery will influence overall brand attitude and brand advocacy behaviors, such as resistance to negative information and positive word of mouth.

\section{H1: Perceived brand bravery will positively influence consumers' brand advocacy behaviors; resistance to negative information (H1a) and positive word of mouth (H1b)}

\section{H2: Perceived brand bravery will positively influence brand attitude}

Extant research on brand personality (Aaker, 1997), extended self-concept (Belk, 1988; Hogg et al., 2000; Sirgy, 1982) and consumer-brand relationships (Fournier, 1998) indicate that consumers use brands as an expression of their own identity. Perspectives from social identity theory also shed light on how brands can represent consumers' social and self-identities (Lam et al., 2012). Consumers use brands they perceive to be a representation of their identities, for selfenhancement purposes. Consumer brand identification is strengthened when a brand meets selfenhancement or self-consistency needs (Bhattacharya and Sen, 2003). Further support exists for symbolic antecedents of identification in the literature (Bhattacharya and Sen, 2003; Kuenzel and Halliday, 2008; Stokburger-Sauer et al., 2012; Tuškej et al., 2013). Wolter et al., (2015) and, 
more recently, Tuškej and Podnar, (2018) provided evidence for the role of brand image and prestige in affecting self-brand identification. Brand bravery will allow consumers to evaluate the level of similarity between the brand and the self, which, in turn, can help an individual express who they are and help them satisfy their needs for self-definition and enhancement. Therefore, it is posited:

\section{H3: Perceived brand bravery will positively influence consumer brand identification}

\subsection{Mediating Effect of self-brand congruity}

Prior research has asserted that brand personality (Aaker, 1997) can influence consumer psychology by aligning with consumers' self-concepts (Malär et al., 2011; Su and Reynolds, 2017). People try to gain self-image congruity by seeking consistency in their external behaviors and internal beliefs (Aaker and Fournier, 1995). In the context of branding, consumers will be inclined towards brands whose image is coherent with the personality, the individual desires to express. Bravery is a value-expressive feature of a brand that the consumers can use to express their own personal values or images, leading to symbolic image congruity. Self-image congruity reflects the match between these value expressive features and the consumers' self-concepts (Sirgy and Johar, 1999). Prior studies indicate that self congruity can yield to various positive outcomes such as favorable attitude towards a brand (Graeff, 1996; Sirgy, 1982), brand preference, purchase intentions and perceived closeness with the brand (Jamal and Al-Marri, 2007; Graeff, 1996; Sirgy et al., 1997). Perceived similarity with the brand can also strengthen self-brand identification (Bhattacharya and Sen, 2003). Therefore, it is inferred that perceived brand bravery will affect brand attitude and consumer-brand identification, both directly and indirectly, through self-brand congruity.

H4: self-brand congruity will mediate the relationship between perceived brand bravery and brand attitude

H5: self-brand congruity will mediate the relationship between perceived brand bravery and consumer brand identification

Based on the hypothesized relationship, the following theoretical framework is proposed 


\subsection{Study 4}

\subsubsection{Procedure}

A total of 220 university students were recruited to participate in the survey in exchange for extra credits. After eliminating incomplete survey responses, 205 responses (56\% Males and 43\% Female, mean age 22 years) were used for analysis. Similar to the method used in earlier studies, participants were asked to think of a brand they consider as brave and briefly provide a reason for it. The hypothesized relationships were tested using Structural Equation Modelling using AMOS v23. Respondents were asked to provide their level of agreement with the scale items of perceived brand bravery and other dependent variables. Four items for resistance to negative information were borrowed from Eisingerich et al. (2011). Three items for positive word of mouth were adapted from Kim et al. (2001) and Xie et al., (2019). Brand attitude was measured using the four items adapted from Edell and Burke, (1987), Mitchell and Olsen (1981) and recently used by Esmark Jones et al., (2018). Self-brand congruity was measured using three items by Sirgy et al. (1997). Four items for consumer brand identification were adapted from earlier studies (Wolter et al., 2015; Tuškej and Podnar, 2018). All items were measured on a five-point Likert scale and are listed in Appendix C.

\subsubsection{Common method variance}

At first, the data were tested for common method variance using Harman's one-factor method (Gunkel et al., 2016; Podsakoff et al., 2003). A single factor was observed to account for $29 \%$ of the total variance, which indicates that common method bias is not present. This was further validated by using confirmatory factor analysis (CFA) test in Amos v23 (Fuller et al., 2016). The value of $\chi^{2}$ of the single-factor CFA model was significantly worse than the multi-factor model. The single-factor CFA model, which had all items loading on one factor $\left(\chi^{2}=3170.711\right.$, df $=819)$, was evaluated against the proposed CFA model with six constructs $\left(\chi^{2}=1251.324, \mathrm{df}=\right.$ 798) using the chi-square difference test. The value of $\Delta \chi^{2}=1919.387$, distributed with $\mathrm{df}=21$, was found significant at $\mathrm{p}<0.001$. This suggests that the proposed measurement model is a better fit compared to the model with the common factor (Werner and Schermelleh-Engel, 2010). This analysis supports that the data is free of common method bias. 


\subsection{Findings}

Some new brands were mentioned as brave in this study. While Apple, Nike, and Amul reappeared in this study, brands like Burger King, Being Human, Coca-Cola, Gillette, Harley-Davidson, Reliance Jio, and Netflix were also reported to be brave by this student sample.

CFA again confirmed the validity of the brave brand scale across the different sample.

Convergent validity was confirmed for all constructs on the basis of the value of alpha, AVE, and composite reliability. Cronbach's alpha for all the constructs was above the criterion of 0.70 , and composite reliability ranged from 0.861 to 0.978 . The AVE was above the desired value of 0.5 (Fornell and Larcker, 1981; Hair et al., 2006). These figures establish the convergent validity of these indicators as distinct latent constructs (Table 6).

\section{---Insert Table 6 here}

All constructs were significantly correlated but also showed discriminant validity in this sample. As per the Fornell-Larcker criterion the AVE of all constructs was found to be greater than the squared correlation among all factors (Table 7). The measurement model fit was satisfactory with $\chi^{2}=1251.324, d f=798, \chi^{2} / d f=1.568, \mathrm{CFI}=0.914$, SRMR $=0.056$ and $\mathrm{RMSEA}=0.056$.

\section{-Insert Table 7 here}

All the proposed hypotheses were supported (Table 8). The strongest effect of brand bravery was observed on brand advocacy behaviors including resistance to negative information $\left(\beta_{\mathrm{H} 1 \mathrm{a}}=\right.$ $0.991, p<0.01)$ and positive word of mouth $\left(\beta_{\mathrm{H} 1 \mathrm{~b}}=1.081, p<0.01\right)$. The direct effects of brand bravery on brand attitude $\left(\beta_{2}=0.569, p<0.01\right)$ and consumer brand identification $\left(\beta_{\mathrm{H} 3}=0.924\right.$, $p<0.01$ ) were also found significant. The model fit for nomological SEM was also found to be satisfactory with $\chi^{2}=1281.837, d f=805, \chi^{2} / d f=1.592, \mathrm{CFI}=0.908, \mathrm{SRMR}=0.08$ and $\mathrm{RMSEA}=0.051$

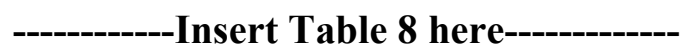

The mediation model was examined using the bootstrapping process recommended by Hayes (2018). For mediation to exist, it is suggested that there must be a significant direct effect of the independent variable (perceived brand bravery) on the outcome variable (consumer-brand 
identification and brand attitude). Thereafter, the significance of direct and indirect effects is checked in the presence of the mediator to assess whether there is partial or full mediation (Hayes, 2018; Preacher et al., 2007). A significant indirect effect supports the presence of a mediating effect. If the direct effect between the independent and dependent variable becomes non-significant, full mediation is indicated whereas if the direct effect continues to be significant, but the effect size is reduced, partial mediation is present.

Results of the mediation analyses summarized in table 9 indicate that both hypothesized paths are partially mediated by self-brand congruity. There was a significant direct effect between brand bravery and brand attitude $(\beta=0.321, \mathrm{p}<0.05)$, and at the same time, the indirect effect was significant $(\beta=0.140, p=0.029)$, providing support for H4. Similarly, the direct effect between brand bravery and consumer brand identification was significant $(\beta=0.547, p<0.01)$ along with a significant indirect path $(\beta=0.225, \mathrm{p}<0.01)$ supporting H5.

\section{-Insert Table 9 here-}

Based on the findings of this study, it can be concluded that the measure of brand bravery has nomological validity. In sum, this study also finds evidence for convergent and discriminant validity, thus lending support to the construct validity of the brand bravery scale.

\section{General Discussion}

The current study establishes the characteristics of brand bravery. A brand can be perceived as brave if it is seen as altruistic, bold, courageous, determined, enduring, fearless, or gritty. Nike was the most frequently mentioned brave brand across studies and perceived as courageous, determined, and fearless. Nike's ad campaign and its creative audacity further strengthen this perception. Respondents reported brands like Mahindra and Tata as brave for their altruistic endeavors. Brands like Maggi and Nokia were mentioned as brave for their grit and endurance in making a comeback after the fallout. KFC is brave for its boldness. Many other brands that are fearless and take chances to innovate and adapt to changing market needs are seen as brave. Overall, the study offers a comprehensive understanding of the concept of brave by conceptualizing the brand bravery construct and developing a valid measure indicating the strength and significance of perceived brand bravery. The final 24 items consisting of seven correlated lower-order factors capture a stable brand bravery structure validated across three 
studies and samples. The scale is psychometrically sound and observed to be distinguishable from other conceptually distinct but related constructs, such as brand integrity, credibility, and trustworthiness. Finally, the nomological framework provides empirical support for theoretical predictions and indicates its effect on positive consumer-related outcomes.

\section{Importance of brand bravery and practical implications}

In a rapidly changing global scenario and growing consumer cynicism, where does the future of brands lie and how to manage the volatility of consumer-brand relationships? This question grew even more pertinent as this study was developed while coursing through the Covid-19 pandemic. Many global brands have come forward to lend their support for different causes in these unprecedented circumstances, moving away from their core product offerings and rising above competitive rivalries to build industrial collaborations. Global brands are currently facing multiple challenges; managing uncertainty, loss of business, communication, and dealing with fake news, to name a few. This crisis is the ideal time for brands to be brave and build resilience to combat these challenges. Being brave is a part of your core identity and not just a business strategy. Brands who are clear in their vision and values will find it easier to be brave and tread through difficult times.

Marketers are forever keen to position their brands that can have a lasting impact on consumers' minds. Experts suggest the need for brands to have a clear and persistent vision (Interbrand, 2018) and willingness to do things differently (Adams, 2018). The dividends of being brave are apparent from the examples of brands like Nike or even Netflix that offer valuable lessons in understanding what the modern conscious consumer expects from brands. These brands were successfully able to withstand market disruptions and stay relevant with their fearless approach and clear long term vision. Research suggests that $86 \%$ consumers prefer brands that take stand for social issues and $64 \%$ of these consumers are willing to purchase from such brands (Shelton Group, 2018). Moreover, millennials are growing increasingly conscious about supporting the brands that care for the community. Recent study on brand activism by Mukherjee and Althuizen (2020) posits that consumers' attitude and behavioral intentions may substantially reduce if they disagree with a brand's stance on a particular socio-political issue. Although being brave goes beyond caring for a cause, it is a crucial strategy to capture the minds of belief-driven consumers, who prefer brands that align with their values. Recent times have witnessed growing turbulence 
on social and political fronts with movements like "black lives matter" receiving solidarity worldwide. In response, Washington's NFL team officially dropped the 87 years old Redskins name for its racial slur. A famous Indian cosmetic brand, "Fair and Lovely" replaces the word "fair" from its name in another incident. Do consumers perceive these actions as truly brave or merely a response under pressure? The current study provides a tool for marketers to assess this perception of consumers.

This research also provides empirical support for the positive outcomes of perceived brand bravery. Perception of bravery in brands can influence advocacy behaviors, including resistance to negative information and positive word of mouth, which is a desirable outcome for brands as they have limited control over the diffusion of information. The findings of the study support that brand bravery can influence self-brand congruity and consumer-brand identification, which are significant drivers of positive consumer-brand relationship (Grohmann, 2009; Maläret al., 2011), including purchase behavior, loyalty and even brand love (Albert and Merunka, 2013; Bergkvist and Bech-Larsen, 2010). Prior research supports that a brand's preceding reputation can act as a buffer against a crisis and facilitate damage repair (Coombs and Holladay, 2001, 2006). Having a brave personality can help brands build a reputation that can deflect post-crisis damage, making them resilient.

Brand bravery provides an important roadmap to marketers who have sought to create a leading brand that stays relevant in these times of disruption. Building on a qualitative study on bravery, the current research provides illustrations of brands perceived as brave, and build an amenable construct for quantitative research. The findings offer insights on what is considered brave and provide a valuable tool that can help marketers create and manage brave brands. The multi-factor scale can help managers track which dimension of the brave brand scale is more relevant for shaping overall bravery perception. This instrument can also be used to test and evaluate the effectiveness of marketing and communication campaigns designed to position the brand as brave. It can also help assess the strategically important outcomes of brand bravery before and after a marketing campaign. Overall, this study can help marketers shape their brands in light of the rapid changes in the future. 


\section{Theoretical implications}

This research contributes to the literature on brand identity and personality by introducing a novel concept of brand bravery. Acknowledging that little is known about the conceptual definition of bravery and its outcomes, the current study is the first to integrate the psychological dimension of bravery in the context of branding literature. Determining if a brand is brave requires demonstrating its ability to survive disruptions, staying true to its values, turning ideas into reality, and fearlessly communicating its beliefs. The results of the study support a multidimensional conceptualization and reflect on the importance of brand bravery. Theoretically, the development and validation of the brave brand scale will strengthen the understanding of this specific brand characteristic.

Marketing scholars have predominantly focused on the brand's CSR image and reputation in leading to positive marketing outcomes (Yoon et al., 2006; Kim and Woo, 2018). The current study focuses on a particular dimensional impact of reputation and explains how being brave can be the future of brands. Further, this study contributes to the consumer-brand relationship and self-concept domain by establishing the relationship between brand bravery and various positive brand-related outcomes, both behavioral and cognitive. The study also offers crucial insights on consumer behavior and perceptions towards a strong and clear brand identity.

\section{Limitations and future directions}

The study is a starting point for a discussion on brand bravery. Many important questions remain to be explored by future research. One is regarding the relation of brand bravery with other brand personality constructs and other emerging brand attributes like brand charisma (Semaan et al., 2019), brand activism (Mukherjee and Althuizen, 2020) and brand authenticity (Morhart et al., 2015). The current study found the effect of brand bravery on attitude and consumer brand identification was partially mediated by self-brand congruity. Although nomological validity supported theoretical prediction, future studies should manipulate other variables and use experiments to establish further causal relationships.

Second, though the results of study 3 and 4 established discriminant validity of brand bravery with other constructs, the study did not employ multitrait-multimethod (MTMM) data, which can provide more robust conclusions regarding discriminant validity. Third, the perceptions of 
bravery can vary due to interpersonal and cultural influences. The current scale development and validation can be further benefited by follow-up analysis using alternate samples, which can also help establish cross-cultural validity. Given that brand bravery is subjective, future studies can also study the influence of individual personality type and other symbolic and brand-related drivers on brand bravery and its outcomes. The buffering effect of brand bravery can also be tested in case of product harm crisis (Kim and Woo, 2018). Finally, future research can study the effect of individual brand bravery dimensions on consumer behavior. Overall, much remains to be explored pertaining to the understanding of brand bravery constructs. Future studies are encouraged to investigate further how this particular novel brand attribute can contribute to the brand's success.

\section{References}

Aaker, J. and Fournier, S., (1995). A brand as a character, a partner and a person: Three perspectives on the question of brand personality. ACR North American Advances.

Aaker, J. L. (1999). The malleable self: The role of self-expression in persuasion. Journal of marketing research, 36(1), 45-57.

Aaker, J.L., (1997). Dimensions of brand personality. Journal of marketing research, 34(3), pp.347-356.

Abitbol, A., Lee, N., Seltzer, T. and Lee, S.Y., (2018). racetogether: Starbucks' attempt to discuss race in America and its impact on company reputation and employees. Public Relations Journal, 12(1), pp.1-28.

Adams, P. (2018), What true brand bravery looks like, according to marketers who took the leap, Marketing Dive, Available at: https://www.marketingdive.com/news/what-true-brand-braverylooks-like-according-to-marketers-who-took-the-lea/539093/

Albert, N. and Merunka, D., (2013). The role of brand love in consumer-brand relationships. Journal of Consumer Marketing. Vol. 30 No. 3, pp. 258-266. https://doi.org/10.1108/07363761311328928

Algoe, S.B. and Haidt, J., (2009). Witnessing excellence in action: The 'other-praising'emotions of elevation, gratitude, and admiration. The journal of positive psychology, 4(2), pp.105-127.

Anderson, J.C. and Gerbing, D.W. (1988), "Structural equation modeling in practice: a review and recommended two-step approach", Psychological Bulletin, Vol. 103 No. 3, pp. 411-423.

Barone, M. J., and Jewell, R. D. (2013). The innovator's license: A latitude to deviate from category norms. Journal of Marketing, 77(1), 120-134. 
Barth C. and Kemp-Robertson P. (2018), The Contagious Commandments: Ten Steps to Brand Bravery, Penguin Books Ltd, London, UK

Bearden, W.O., Netemeyer, R. and Mobley, M.F. (1993), Handbook of Marketing Scales, Sage Publication, Newburg Park, CA.

Becker, S.W. and Eagly, A.H., (2004). The heroism of women and men. American Psychologist, 59(3), p.163.

Belk, R.W. (1988), "Possessions and the extended self", Journal of Consumer Research, Vol. 15No. 2, pp. 139-168.

Bellezza, S., Gino, F., and Keinan, A. (2014). The red sneakers effect: Inferring status and competence from signals of nonconformity. Journal of consumer research, 41(1), 35-54.

Bergkvist, L. and Bech-Larsen, T., (2010). Two studies of consequences and actionable antecedents of brand love. Journal of brand management, 17(7), pp.504-518.

Bhattacharya, C.B. and Sen, S. (2003), "Consumer-company identification: a framework for understanding consumers' relationships with companies", Journal of Marketing, Vol. 67 No. 2, pp. 76-88.

Byrne, B. M. (2013). Structural equation modeling with AMOS: Basic concepts, applications, and programming. Routledge.

Coombs, W. T., and Holladay, S. J. (2011). An exploration of the effects of victim visuals on perceptions and reactions to crisis events. Public Relations Review, 37(2), 115-120. https://doi.org/10.1016/j.pubrev.2011.01.006

Coombs, W.T. and Holladay, S.J., (2001). An extended examination of the crisis situations: A fusion of the relational management and symbolic approaches. Journal of public relations research, 13(4), pp.321-340.

Coombs, W.T. and Holladay, S.J., (2006). Unpacking the halo effect: Reputation and crisis management. Journal of Communication Management. Vol. 10 No. 2, pp. 123-137. https://doi.org/10.1108/13632540610664698

Davis, K. (2018). Brave Leadership: Unleash Your Most Confident, Powerful, and Authentic Self to Get the Results You Need. Greenleaf Book Group.

De Chernatony, L., (2002). Would a brand smell any sweeter by a corporate name? Corporate reputation review, 5(2-3), pp.114-132.

Dodd, M.D. and Supa, D., (2015). Testing the viability of corporate social advocacy as a predictor of purchase intention. Communication Research Reports, 32(4), pp.287-293.

Dorner, A. (2012). Morally Adaptive or Morally Maladaptive: A Look at Compassion, Mercy, and Bravery. ESSAI, 10(1), 17.

Dunlop, W.L. and Walker, L.J., (2013). The personality profile of brave exemplars: A personcentered analysis. Journal of Research in Personality, 47(4), pp.380-384. 
Edell, J.A. and Burke, M.C., (1987). The power of feelings in understanding advertising effects. Journal of Consumer research, 14(3), pp.421-433.

Edelman (2018). Earned brand. Available at:

https://www.edelman.com/sites/g/files/aatuss191/files/2018-

10/2018_Edelman_Earned_Brand_Executive_Summary_Brochure.pdf

Edison Trends, (2018). "Nike Online Sales Grew 31\% Over Labor Day Weekend and

Kaepernick Ad Campaign" available at: https://trends.edison.tech/research/nike-labor-day2018.html

Eisingerich, A.B., Rubera, G., Seifert, M. and Bhardwaj, G., (2011). Doing good and doing better despite negative information?: The role of corporate social responsibility in consumer resistance to negative information. Journal of Service Research, 14(1), pp.60-75.

Erdem, T. and Swait, J., (2004). Brand credibility, brand consideration, and choice. Journal of consumer research, 31(1), pp.191-198.

Esmark Jones, C.L., Stevens, J.L., Breazeale, M. and Spaid, B.I., (2018). Tell it like it is: The effects of differing responses to negative online reviews. Psychology and Marketing, 35(12), pp.891-901.

Fornell, C., and Larcker, D. F. (1981). Structural equation models with unobservable variables and measurement error: Algebra and statistics. Journal of Marketing Research, 18(3), 382-388. https://doi.org/10.2307/3150980.

Foroudi, P., Melewar, T.C. and Gupta, S. (2014), "Linking corporate logo, corporate image, and reputation: an examination of consumer perceptions in the financial setting", Journal of Business Research, Vol. 67 No. 11, pp. 2269-2281.

Fournier, S. (1998). Consumers and their brands: Developing relationship theory in consumer research. Journal of consumer research, 24(4), 343-373.

Franco, Z. and Zimbardo, P., (2006). The banality of heroism. Greater Good, 3(2), pp.30-35.

Franco, Z.E., Blau, K. and Zimbardo, P.G., (2011). Heroism: A conceptual analysis and differentiation between heroic action and altruism. Review of general psychology, 15(2), pp.99113.

Frynas, J.G., Child, J. and Tarba, S.Y., (2017). Non-market social and political strategies-new integrative approaches and interdisciplinary borrowings. British Journal of Management, 28(4), pp.559-574.

Fuller, C.M., Simmering, M.J., Atinc, G., Atinc, Y. and Babin, B.J., (2016). Common methods variance detection in business research. Journal of Business Research, 69(8), pp.3192-3198.

Gilliam, D. A., and Voss, K. (2013). A proposed procedure for construct definition in marketing. European Journal of Marketing. Vol. 47 No. 1/2, pp. 5-26.

https://doi.org/10.1108/03090561311285439 
Goertz, G. (2006), Social Science Concepts: A User's Guide, Princeton University Press, Princeton, NJ.

Graeff, T.R., (1996). Using promotional messages to manage the effects of brand and self-image on brand evaluations. Journal of consumer marketing. Vol. 13 No. 3, pp. 4-18. https://doi.org/10.1108/07363769610118921

Grohmann, B., (2009). Gender dimensions of brand personality. Journal of marketing research, 46(1), pp.105-119.

Gunkel, M., Schlaegel, C. and Taras, V., (2016). Cultural values, emotional intelligence, and conflict handling styles: A global study. Journal of World Business, 51(4), pp.568-585.

Hair, J. F., Anderson, R., Tatham, R., and Black, W. (2006). Multivariate data analysis (6th ed.). New Jersey: Prentice Hall.

Hair, J. F., Black, W. C., Babin, B. J., and Anderson, R. E. (2010). Multivariate data analysis (7rd ed.). Upper Saddle River, New Jersey: Pearson Prentice Hall.

Harris, F. and de Chernatony, L. (2001), "Corporate branding and corporate brand performance", European Journal of Marketing, Vol. 35 No. 3/4, pp. 441-456.

https://doi.org/10.1108/03090560110382101

Hayes, A. F. (2018). Partial, conditional, and moderated moderated mediation: Quantification, inference, and interpretation. Communication Monographs, 85(1), 4-40.

He, H., and Harris, L. (2020). The Impact of Covid-19 Pandemic on Corporate Social Responsibility and Marketing Philosophy. Journal of Business Research. 116, pp. 176-182

Hoffmann, J., Nyborg, K., Averhoff, C., and Olesen, S. (2020). The contingency of corporate political advocacy: Nike's 'dream crazy'campaign with Colin Kaepernick. Public Relations Inquiry, 9(2), DOI: https://doi.org/10.1177\%2F2046147X20920802

Hogg, M.K., Cox, A.J. and Keeling, K., (2000). The impact of self-monitoring on image congruence and product/brand evaluation. European journal of marketing. Vol. 34 No. 5/6, pp. 641-667. https://doi.org/10.1108/03090560010321974

Hu, L.T. and Bentler, P.M., (1999). Cutoff criteria for fit indexes in covariance structure analysis: Conventional criteria versus new alternatives. Structural equation modeling: a multidisciplinary journal, 6(1), pp.1-55.

Hutchinson, A., Stuart, A., and Pretorius, H. (2010). Biological contributions to well-being: The relationships amongst temperament, character strengths and resilience. SA Journal Of Industrial Psychology, 36(2), 1-10. doi: http://dx.doi.org/10.4102/sajip.v36i2.844

Interbrand (2018), "Activating Brave", Best global brands 2018

Jamal, A. and Al-Marri, M., (2007). Exploring the effect of self-image congruence and brand preference on satisfaction: the role of expertise. Journal of Marketing Management, 23(7-8), pp.613-629. 
Jayawickreme, E. and Di Stefano, P., (2012). How can we study heroism? Integrating persons, situations and communities. Political Psychology, 33(1), pp.165-178.

Jordan, J. V. (2005). Relational resilience in girls. In E. Goldstein \& R. B. Brooks (Eds.), Handbook of resilience in children (pp.91-105). New York, NY: Springer

Jung, C.G., (1938). Psychological aspects of the mother archetype. CE 9i, par, 149, p.76.

Kapferer, J.N., (2012). The new strategic brand management: Advanced insights and strategic thinking. Kogan page publishers.

Kim, C.K., Han, D. and Park, S.B., (2001). The effect of brand personality and brand identification on brand loyalty: Applying the theory of social identification. Japanese psychological research, 43(4), pp.195-206.

Kim, J.K., Overton, H., Bhalla, N. and Li, J.Y., (2019). Nike, Colin Kaepernick, and the politicization of sports: Examining perceived organizational motives and public responses. Public Relations Review, p.101856.

Kim, Y. and Woo, C.W., (2019). The buffering effects of CSR reputation in times of productharm crisis. Corporate Communications: An International Journal.

https://doi.org/10.1108/CCIJ-02-2018-0024

Kinsella, E.L., Ritchie, T.D. and Igou, E.R., (2015). Zeroing in on heroes: A prototype analysis of hero features. Journal of personality and social psychology, 108(1), p.114.

Kinsella, E.L., Ritchie, T.D. and Igou, E.R., (2017). On the bravery and courage of heroes: considering gender. Heroism Science, 2(1), p.4.

Kuenzel, S. and Vaux Halliday, S. (2008), "Investigating antecedents and consequences ofbrand identification", Journal of Product and Brand Management, Vol. 17 No. 5, pp. 293-304.

Lam, S.K., Ahearne, M. and Schillewaert, N. (2012), "A multinational examination of the symbolic-instrumental framework of consumer-brand identification", Journal of International Business Studies, Vol. 43 No. 3, pp. 306-331.

Lee, H. S., and Cho, C. H. (2012). Sporting event personality: Scale development and sponsorship implications. International Journal of Sports Marketing \& Sponsorship, vol. 14, no. 1, pp. $51-68$

Levenson, M. R. (1990). Risk taking and personality. Journal of personality and social psychology, 58(6), 1073.

Lin, J.S. and Sung, Y., (2014). Nothing can tear us apart: The effect of brand identity fusion in consumer-brand relationships. Psychology and Marketing, 31(1), pp.54-69.

London, P. (1970). The rescuers: Motivational hypotheses about Christians who saved Jews from the Nazis. In J. Macaulay and L. Berkowitz (Eds.), Altruism and helping behavior: Social psychological studies of some antecedents and consequences (pp. 241-250). New York: Academic Press. 
Lord, H. G. (1918). The psychology of courage. Boston: John W. Luce.

MacKenzie, S.B., Podsakoff, P.M. and Podsakoff, N.P. (2011), "Construct measurement and validation procedures in MIS and behavioral research: Integrating new and existing techniques", MIS Quarterly, 35(2), pp. 293-334.

Malär, L., Krohmer, H., Hoyer, W.D. and Nyffenegger, B., (2011). Emotional brand attachment and brand personality: The relative importance of the actual and the ideal self. Journal of marketing, 75(4), pp.35-52.

Martínez-Martí, M. L., and Ruch, W. (2017). Character strengths predict resilience over and above positive affect, self-efficacy, optimism, social support, self-esteem, and life satisfaction. The Journal of Positive Psychology, 12(2), 110-119.

McCullough, M.E., Kimeldorf, M.B. and Cohen, A.D., (2008). An adaptation for altruism: The social causes, social effects, and social evolution of gratitude. Current directions in psychological science, 17(4), pp.281-285.

Mitchell, A.A. and Olson, J.C., (1981). Are product attributes the only mediator of advertising effects on brand attitude: A second look. Journal Marketing Research, 27, pp.109-219.

Morhart, F., Malär, L., Guèvremont, A., Girardin, F. and Grohmann, B., (2015). Brand authenticity: An integrative framework and measurement scale. Journal of Consumer Psychology, 25(2), pp.200-218.

Mukherjee, R., and Banet-Weiser, S. (Eds.). (2012). Commodity activism: Cultural resistance in neoliberal times. NYU Press.

Mukherjee, S. and Althuizen, N., (2020). Brand activism: Does courting controversy help or hurt a brand?. International Journal of Research in Marketing.

https://doi.org/10.1016/j.ijresmar.2020.02.008

Odoom, R., Kosiba, J.P., Djamgbah, C.T. and Narh, L., (2019). Brand avoidance: underlying protocols and a practical scale. Journal of Product and Brand Management.

https://doi.org/10.1108/JPBM-03-2018-1777

Oliner, S. P. (2003). Do unto others: Extraordinary acts of ordinary people. Boulder, CO: Westview Press.

Park, K. and Jiang, H., (2020). Signaling, Verification, and Identification: The Way Corporate Social Advocacy Generates Brand Loyalty on Social Media. International Journal of Business Communication, p.2329488420907121.

Patton, M.Q. (2001), Qualitative Research \& Evaluation Methods, 3rd ed., Sage, Thousand Oaks, Calif.

Pearson, C. and Mark, M., (2001). The hero and the outlaw: Building extraordinary brands through the power of archetypes. New Jork: McGraw-Hill.

Peterson, C. (2006). A primer in positive psychology. New York: Oxford University Press. 
Peterson, C. and Seligman, M.E.P., (2004). Character strengths and virtues: A classification ion and handbook.

Podsakoff, P.M., MacKenzie, S.B. and Podsakoff, N.P. (2016), "Recommendations for creating better concept definitions in the organizational, behavioral, and social sciences", Organizational Research Methods, 19 (2), pp. 159-203.

Podsakoff, P.M., MacKenzie, S.B., Lee, J.Y. and Podsakoff, N.P., (2003). Common method biases in behavioral research: a critical review of the literature and recommended remedies. Journal of applied psychology, 88(5), p.879.

Preacher, K. J., Rucker, D. D., and Hayes, A. F. (2007). Assessing moderated mediation hypotheses: Theory, method, and prescription. Multivariate Behavioral Research, 42, 185-227.

Ruch, W., and Proyer, R. T. (2015). Mapping strengths into virtues: The relation of the 24 VIAstrengths to six ubiquitous virtues. Frontiers in Psychology, 6, pp.460.

Schultz, A. (2020). LVMH Converts Perfume Production to Hand Sanitizer, available at: https://www.barrons.com/articles/lvmh-converts-perfume-production-to-hand-sanitizer01584380869

Seligman, M. E. P. (2002a). Authentic happiness. New York: The Free Press.

Seligman, M. E. P. (2011). Flourish. New York: The Free Press

Semaan, R.W., Ashill, N. and Williams, P., (2019). Sophisticated, iconic and magical: A qualitative analysis of brand charisma. Journal of Retailing and Consumer Services, 49, pp.102113.

Sirgy, M. J. (1982). Self-concept in consumer behavior: A critical review. Journal of consumer research, 9(3), 287-300.

Sirgy, M.J. and Johar, J.S., (1999). Toward an integrated model of self-congruity and functional congruity. ACR European Advances.

Sirgy, M.J., (1982). Self-concept in consumer behavior: a critical review. Journal of consumer research, 287-300.

Sirgy, M.J., Grewal, D., Mangleburg, T.F., Park, J.O., Chon, K.S., Claiborne, C.B., Johar, J.S. and Berkman, H., (1997). Assessing the predictive validity of two methods of measuring selfimage congruence. Journal of the academy of marketing science, 25(3), p.229.

Smith, N. (2016), "Brand Archetypes - Meet the Hero", Nvision Designs, Available at: http://www.nvision-that.com/design-from-all-angles/brand-archetype-the-hero

Smith, S. and Milligan, A. (2011). Bold: How to be Brave in Business and Win, Kogan Page Publishers, London, UK

Sobande, F. (2019). Woke-washing:"Intersectional" femvertising and branding "woke" bravery. European Journal of Marketing. Doi: https://doi.org/10.1108/EJM-02-2019-0134 
Stokburger-Sauer, N., Ratneshwar, S. and Sen, S. (2012), "Drivers of consumer-brand identification", International Journal of Research in Marketing, Vol. 29No.4,pp. 406-418.

Strauss, A., Corbin, J., (1994). Grounded theory methodology. Handbook of Qual. Res. 17, 273285.

$\mathrm{Su}, \mathrm{N}$. and Reynolds, D., (2017). Effects of brand personality dimensions on consumers' perceived self-image congruity and functional congruity with hotel brands. International Journal of Hospitality Management, 66, pp.1-12.

Tuškej, U. and Podnar, K., (2018). Consumers' identification with corporate brands: Brand prestige, anthropomorphism and engagement in social media. Journal of Product and Brand Management. Vol. 27 No. 1, pp. 3-17. https://doi.org/10.1108/JPBM-05-2016-1199

Tuškej, U., Golob, U. and Podnar, K. (2013), "The role of consumer-brand identification in building Brand relationships", Journal of Business Research, Vol. 66No. 1, pp. 53-59.

Walker, L.J. and Frimer, J.A., (2007). Moral personality of brave and caring exemplars. Journal of personality and social psychology, 93(5), p.845.

Walker, L.J. and Hennig, K.H., (2004). Differing conceptions of moral exemplarity: just, brave, and caring. Journal of personality and social psychology, 86(4), p.629.

Walker, L.J., Frimer, J.A. and Dunlop, W.L., (2010). Varieties of moral personality: Beyond the banality of heroism. Journal of personality, 78(3), pp.907-942.

Werner, C., and Schermelleh-Engel, K. (2010). Introduction to structural equation modeling with LISREL. Goethe University, Frankfurt. Retrieved on February, 5, 2011.

Wolter, J.S., Brach, S., Cronin Jr, J.J. and Bonn, M., (2016). Symbolic drivers of consumerbrand identification and disidentification. Journal of Business Research, 69(2), pp.785-793.

Xie, C., Bagozzi, R.P. and Grønhaug, K., (2019). The impact of corporate social responsibility on consumer brand advocacy: The role of moral emotions, attitudes, and individual differences. Journal of Business Research, 95, pp.514-530.

Yi, Y. and Gong, T., (2013). Customer value co-creation behavior: Scale development and validation. Journal of Business research, 66(9), pp.1279-1284.

Yoon, Y., Gürhan-Canli, Z. and Schwarz, N., (2006). The effect of corporate social responsibility (CSR) activities on companies with bad reputations. Journal of consumer psychology, 16(4), pp.377-390.

Zaichkowsky, J.L. (1985), "Measuring the involvement construct", Journal of Consumer Research, Vol. 12 No. 3, pp. 341-352. 
Table 1: Definitions of bravery

\begin{tabular}{|c|c|c|c|}
\hline Construct & Stream & Definition and characteristics & Citation \\
\hline $\begin{array}{l}\text { Bravery } \\
\text { (adjective) }\end{array}$ & Psychology & $\begin{array}{l}\text { Willingly risking one's life for } \\
\text { others }\end{array}$ & Lord, 1918 \\
\hline $\begin{array}{l}\text { Brave } \\
\text { (personality) }\end{array}$ & Psychology & $\begin{array}{l}\text { Heightened sense of } \\
\text { adventurousness }\end{array}$ & London, 1970 \\
\hline $\begin{array}{l}\text { Brave } \\
\text { (personality) }\end{array}$ & Psychology & Personal efficacy and optimism & Oliner, 2003 \\
\hline $\begin{array}{l}\text { Brave } \\
\text { (personality) }\end{array}$ & Psychology & $\begin{array}{l}\text { Heightened motivations and } \\
\text { inherently redemptive }\end{array}$ & $\begin{array}{l}\text { Walker and Frimer } \\
(2007)\end{array}$ \\
\hline $\begin{array}{l}\text { Brave } \\
\text { (personality) }\end{array}$ & $\begin{array}{l}\text { Morality and } \\
\text { positive } \\
\text { psychology }\end{array}$ & Caring and moral excellence & $\begin{array}{l}\text { Walker, Frimer, and } \\
\text { Dunlop (2010) }\end{array}$ \\
\hline $\begin{array}{l}\text { Brave } \\
\text { (personality) }\end{array}$ & Psychology & $\begin{array}{l}\text { a distinctive personality } \\
\text { characterized by dominance } \\
\text { (behavioral), need for personal } \\
\text { growth (characteristic } \\
\text { adaptations) and early life } \\
\text { elements such as redemptions } \\
\text { and early advantages } \\
\text { (integrative life are underlying } \\
\text { traits elements) leading to } \\
\text { exceptional bravery }\end{array}$ & $\begin{array}{l}\text { Dunlop and Walker } \\
\text { (2013) }\end{array}$ \\
\hline $\begin{array}{l}\text { Bravery } \\
\text { (character } \\
\text { strength of } \\
\text { Heroism) }\end{array}$ & $\begin{array}{l}\text { Morality and } \\
\text { positive } \\
\text { psychology }\end{array}$ & $\begin{array}{l}\text { commitment to noble causes } \\
\text { and welfare of others and } \\
\text { propensity to make sacrifices to } \\
\text { achieve their purpose }\end{array}$ & $\begin{array}{l}\text { Franco et al., 2011; } \\
\text { Franco and Zimbardo, } \\
\text { 2006; Becker and Eagly, } \\
2004\end{array}$ \\
\hline $\begin{array}{l}\text { Bravery } \\
\text { (character } \\
\text { strength of } \\
\text { Heroism) }\end{array}$ & $\begin{array}{l}\text { Morality and } \\
\text { positive } \\
\text { psychology }\end{array}$ & $\begin{array}{l}\text { Courage shown by rescuers of } \\
\text { the weak }\end{array}$ & $\begin{array}{l}\text { London, 1970; } \\
\text { Jayawickreme and } \\
\text { Stefano, 2012; Dunlop } \\
\text { and Walker, 2013 }\end{array}$ \\
\hline $\begin{array}{l}\text { Bravery } \\
\text { (character } \\
\text { strength of } \\
\text { Courage) }\end{array}$ & Psychology & $\begin{array}{l}\text { Classified under the virtue of } \\
\text { courage, bravery means not } \\
\text { shrinking from threat, } \\
\text { challenge, difficulty, or pain }\end{array}$ & $\begin{array}{l}\text { Ruch and Proyer (2015); } \\
\text { Martínez-Martí \& Ruch } \\
\text { (2017). }\end{array}$ \\
\hline $\begin{array}{l}\text { Brave } \\
\text { (personality) }\end{array}$ & $\begin{array}{l}\text { Personality } \\
\text { and social } \\
\text { psychology }\end{array}$ & Pro-social risk takers, or heroes & Levenson, 1990 \\
\hline
\end{tabular}




\begin{tabular}{|l|l|l|l|}
\hline $\begin{array}{l}\text { Bravery } \\
\text { (adjective) }\end{array}$ & $\begin{array}{l}\text { Morality and } \\
\text { positive } \\
\text { psychology }\end{array}$ & $\begin{array}{l}\text { Knowingly putting oneself in } \\
\text { harm's way, be it physical, } \\
\text { mental, or social; coming to the } \\
\text { aid of others and conquering } \\
\text { fears }\end{array}$ & Dorner 2012 \\
\hline Brave & $\begin{array}{l}\text { Marketing } \\
\text { and } \\
\text { advertising }\end{array}$ & $\begin{array}{l}\text { media representations depicting } \\
\text { racial and gender issues }\end{array}$ & Sobande, 2019 \\
\hline Brave & $\begin{array}{l}\text { Branding and } \\
\text { advertising }\end{array}$ & Commodity and brand activism & $\begin{array}{l}\text { Mukherjee and Banet- } \\
\text { Weiser, 2012 }\end{array}$ \\
\hline
\end{tabular}

Table 2. Dimensions of brand bravery

\begin{tabular}{|c|c|c|c|}
\hline $\begin{array}{l}\text { Characteristics } \\
\text { / dimensions / } \\
\text { themes } \\
\text { identified from } \\
\text { Qual study }\end{array}$ & Definition & $\begin{array}{l}\text { Illustration / quotes from qualitative } \\
\text { study }\end{array}$ & $\begin{array}{l}\text { Supporting } \\
\text { literature }\end{array}$ \\
\hline Altruism & $\begin{array}{l}\text { The brand thinks } \\
\text { of the greater good } \\
\text { of different } \\
\text { stakeholders, } \\
\text { environment and } \\
\text { society at large } \\
\text { and displays } \\
\text { socially } \\
\text { responsible } \\
\text { conduct }\end{array}$ & $\begin{array}{l}\text { "Lego - which makes us think of } \\
\text { plastic bricks - reformulated the literal } \\
\text { essence of its product when they } \\
\text { replaced traditional plastic toys with } \\
\text { sugarcane plastic. The brand's } \\
\text { commitment to cut the use of plastic to } \\
\text { save the environment is one of a kind." } \\
\text { "Burger king agreed to melt all plastic } \\
\text { toys and offered to give free meals to } \\
\text { all those who brought back the plastic } \\
\text { toys (including those of MacDonald's). } \\
\text { All this due to the petition by } 2 \text { sisters } \\
\text { aged } 7 \text { and } 9 \text { to get the fast food giant } \\
\text { to stop giving away free plastic toys." }\end{array}$ & $\begin{array}{l}\text { Becker and } \\
\text { Eagly, } \\
\text { (2004); } \\
\text { Peterson, } \\
\text { (2006); } \\
\text { Dunlop and } \\
\text { Walker, } \\
\text { (2013) }\end{array}$ \\
\hline Bold & $\begin{array}{l}\text { Characterized by } \\
\text { non conformity to } \\
\text { industry standards } \\
\text { or stereotypes }\end{array}$ & $\begin{array}{l}\text { Netflix brought an industry } \\
\text { breakthrough and changed the } \\
\text { consumer's entertainment consumption } \\
\text { preferences by giving rise to the era of } \\
\text { Binge Watching. It showed quite some } \\
\text { grit especially after it failed to land up } \\
\text { with a contract to stream HBO content. } \\
\text { It still went ahead and invested millions }\end{array}$ & $\begin{array}{l}\text { Smith and } \\
\text { Milligan } \\
(2011)\end{array}$ \\
\hline
\end{tabular}




\begin{tabular}{|c|c|c|c|}
\hline & & $\begin{array}{l}\text { of dollars to stream all episodes of } \\
\text { house of cards together. The brand } \\
\text { hasn't looked back since then. It's truly } \\
\text { amazing how they changed the } \\
\text { dynamics of TV viewing." }\end{array}$ & \\
\hline Confident & $\begin{array}{l}\text { A positive } \\
\text { characteristics } \\
\text { where the brand } \\
\text { does not deter } \\
\text { from admitting } \\
\text { when it is wrong, } \\
\text { is sure of itself } \\
\text { and thus confident } \\
\text { to acknowledge its } \\
\text { flaws }\end{array}$ & $\begin{array}{l}\text { "When a fast food brand runs out of its } \\
\text { key ingredient but KFC used } \\
\text { transparency and apologized for its } \\
\text { chicken shortfall. In fact KFC used } \\
\text { humor to persuade its customers to wait } \\
\text { and trust them till they get back to } \\
\text { doing what they are really good at. } \\
\text { They came up with FCK apology to } \\
\text { respond to the chicken shortfall". }\end{array}$ & $\begin{array}{l}\text { Davis } \\
\text { (2018) }\end{array}$ \\
\hline Determined & $\begin{array}{l}\text { The brand takes a } \\
\text { stand for what it } \\
\text { believes in, is } \\
\text { resolute, } \\
\text { uninhibited and } \\
\text { clearly } \\
\text { communicates its } \\
\text { stand on } \\
\text { controversial } \\
\text { issues }\end{array}$ & $\begin{array}{l}\text { "Despite facing the music, Nike stood } \\
\text { by its decision to run the campaign } \\
\text { with Colin Kaepernick - former NFL } \\
\text { player who got banned for protesting } \\
\text { against racial abuse, by kneeling down } \\
\text { During a national anthem. Nike didn't } \\
\text { care what its customer will think of the } \\
\text { brand." } \\
\text { "Starbucks employed 10,000 refugees } \\
\text { when US president Donald Trump put } \\
\text { forward the immigration ban on middle } \\
\text { eastern countries - reaffirming its } \\
\text { identity as a brand which is liberal, } \\
\text { accommodating and welcoming to } \\
\text { every individual regardless of race, } \\
\text { class, ethnicity or gender." }\end{array}$ & $\begin{array}{l}\text { Lee and } \\
\text { Cho (2012) }\end{array}$ \\
\hline Enduring & $\begin{array}{l}\text { Characterizes true } \\
\text { strength of the } \\
\text { brand who can } \\
\text { sustain even the } \\
\text { turbulent times, } \\
\text { has a strong spirit } \\
\text { to recover from } \\
\text { failures and is } \\
\text { resilient }\end{array}$ & $\begin{array}{l}\text { Nokia was on the top and ruled the } \\
\text { Indian market till } 2011-13 \text {, till it faced } \\
\text { losses and was forced to shut down. } \\
\text { But today, Nokia has made a comeback } \\
\text { to the Indian market, competing with } \\
\text { already established brands and making } \\
\text { a name for itself once again. } \\
\text { Maggi launched the same product with } \\
\text { a Rs. } 2 \text { price hike even after the big }\end{array}$ & $\begin{array}{l}\text { Martínez- } \\
\text { Martí and } \\
\text { Ruch } \\
(2017) \text {. }\end{array}$ \\
\hline
\end{tabular}




\begin{tabular}{|l|l|l|l|}
\hline & & $\begin{array}{l}\text { defamation caused due to high lead } \\
\text { content case which was followed by } \\
\text { halting of Maggi's production and } \\
\text { distribution, burning of existing Maggi } \\
\text { stock - it was brave of Maggi to come } \\
\text { back after such a backlash }\end{array}$ & \\
\hline Fearless & $\begin{array}{l}\text { The brand is not } \\
\text { afraid to explore } \\
\text { unchartered } \\
\text { territories, has the } \\
\text { courage to tread } \\
\text { unknown waters, } \\
\text { takes risks, and } \\
\text { open to innovate }\end{array}$ & $\begin{array}{l}\text { "Despite being trolled so much on } \\
\text { social media, Apple doesn't stop from } \\
\text { innovating. It was daring on apple's } \\
\text { part to launch a phone without a } \\
\text { headphone jack - despite that the brand } \\
\text { holds a strong position in the market } \\
\text { and is loved by many. It also had the } \\
\text { guts to launch a completely new and } \\
\text { different iOS platform in a market } \\
\text { ruled by Windows" } \\
\text { "Adidas risked so much by launching } \\
\text { the 'superstar' sneakers which were } \\
\text { very popular in the 80's. This was very } \\
\text { unconventional and brave I believe" }\end{array}$ & $\begin{array}{l}\text { Levenson } \\
\text { (1990); } \\
\text { Jordan } \\
\text { (2005); } \\
\text { (2017). }\end{array}$ \\
\hline
\end{tabular}

Table 3: Final items retained after CFA and loadings

\begin{tabular}{lll}
\hline Factor & Statement & Loadings \\
\hline Altruism & $\begin{array}{l}\text { The Brand is socially responsible and employs sustainable } \\
\text { business practices }\end{array}$ & .714 \\
& $\begin{array}{l}\text { The Brand believes in the greater good } \\
\text { The Brand goes above and beyond its own interest to benefit } \\
\text { others }\end{array}$ & .626 \\
& $\begin{array}{l}\text { This Brand is not afraid to adapt its strategies if it benefits the } \\
\text { society at large }\end{array}$ & .621 \\
& This Brand is willing to reinvent itself for a cause & .617 \\
\hline Bold & The Brand has a path distinct from its competitors & .684 \\
& The Brand acknowledges its constraints & .609 \\
& The brand is unyielding and sticks to its ground even if doing & .593 \\
& so may cost its business & .544 \\
\hline The Brand is true to itself & .755 \\
\hline Courageous & The Brand is not afraid to declare its flaws & .711 \\
& The Brand concedes its mistakes & \\
\hline
\end{tabular}




\begin{tabular}{lll}
\hline Determined & $\begin{array}{l}\text { The brand remains relentless and refuses to succumb to } \\
\text { external power }\end{array}$ & .739 \\
& The Brand challenges the status quo & .542 \\
& The brand is resolute and holds on to its Values & .538 \\
& The spirit of the Brand remains unshaken despite failures & .534 \\
\hline Enduring & The Brand stands up to its competitors & .736 \\
& The Brand challenges itself & .577 \\
& The Brand has a never-say-die vision & .487 \\
\hline Fearless & The Brand is fearless in venturing into new territories & .778 \\
& The Brand defines new frontiers in business & .640 \\
& The Brand is courageous in taking chances / risks & .614 \\
\hline Gritty & The Brand is revolutionary and questions the existing & .806 \\
& stereotypes & .609 \\
& The Brand is innovative and defies the industry norms & .500 \\
\hline
\end{tabular}

Table 4: Test of Chi-square Difference

\begin{tabular}{lllllll}
\hline Construct Pair & $\chi \mathbf{2}$ & DF & $\chi \mathbf{2} / \mathbf{D F}$ & CFI & RMSEA & SRMR \\
\hline $\begin{array}{l}\text { Brand Bravery/Brand Integrity } \\
\text { Single factor model }\end{array}$ & 1618.221 & 344 & 4.704 & 0.649 & 0.111 & 0.293 \\
Two factor model & 495.366 & 343 & 1.444 & 0.958 & 0.039 & 0.045 \\
\hline Brand Bravery/Brand Credibility & & & & & & \\
Single factor model & 659.33 & 318 & 2.073 & 0.88 & 0.06 & 0.064 \\
Two factor model & 465.307 & 317 & 1.468 & 0.951 & 0.04 & 0.046 \\
\hline Brand Bravery/Brand Trustworthiness & & & & & & \\
Single factor model & 1613.697 & 371 & 4.35 & 0.692 & 0.106 & 0.282 \\
Two Factor model & 490.277 & 370 & 1.325 & 970 & 0.033 & 0.043 \\
\hline
\end{tabular}


Table 5: Discriminant validity of brand bravery with other correlated constructs

\begin{tabular}{lcc}
\hline Construct & AVE & $\mathbf{r}^{2}$ between constructs \\
\hline Perceived Band bravery & 0.778 & \\
Brand integrity & 0.75 & 0.64 \\
Brand credibility & 0.69 & 0.36 \\
Brand trustworthiness & 0.741 & 0.28 \\
\hline
\end{tabular}

Discriminant validity supported according to Fornell-Larcker criterion

Table 6: Convergent validity (study 4)

\begin{tabular}{llll}
\hline & Alpha & CR & AVE \\
\hline Perceived brand bravery & $\mathbf{0 . 9 2 3}$ & 0.978 & 0.866 \\
Self brand congruity & $\mathbf{0 . 8 6 1}$ & 0.868 & 0.691 \\
Consumer brand identification & $\mathbf{0 . 8 4 2}$ & 0.861 & 0.608 \\
Resistance to negative information & $\mathbf{0 . 8 7 3}$ & 0.919 & 0.739 \\
Brand attitude & $\mathbf{0 . 9 0 5}$ & 0.889 & 0.668 \\
Positive word of mouth & $\mathbf{0 . 8 7 6}$ & 0.89 & 0.729 \\
\hline
\end{tabular}

Table 7: Discriminant validity (study 4)

\begin{tabular}{|c|c|c|c|c|c|c|}
\hline & Brave & $\mathrm{SBC}$ & $\mathrm{CBI}$ & RNI & ATT & PWOM \\
\hline Perceived brand bravery & 0.931 & & & & & \\
\hline Self brand congruity & $0.696^{* * *}$ & 0.831 & & & & \\
\hline $\begin{array}{l}\text { Consumer brand } \\
\text { identification }\end{array}$ & $0.677 * * *$ & $0.778 * * *$ & 0.78 & & & \\
\hline $\begin{array}{c}\text { Resistance to negative } \\
\text { information }\end{array}$ & $0.629 * * *$ & $0.418 * * *$ & $0.448 * * *$ & 0.86 & & \\
\hline Brand attitude & $0.432 * * *$ & $0.573 * * *$ & $0.527^{* * *}$ & $0.391 * * *$ & 0.817 & \\
\hline Positive word of mouth & $0.698 * * *$ & $0.654 * * *$ & $0.741 * * *$ & $0.617 * * *$ & $0.540 * * *$ & 0.854 \\
\hline
\end{tabular}


Table 8: Direct Effects (study 4)

\begin{tabular}{|c|c|c|c|c|c|}
\hline & Hypothesis & Estimate & t-statistic & $\mathbf{p}$ & $\begin{array}{l}\text { Hypothesis } \\
\text { supported }\end{array}$ \\
\hline Brave $\rightarrow$ RNI & H1a & 0.991 & 6.303 & 0.00 & Yes \\
\hline Brave $\rightarrow$ PWOM & $\mathrm{H} 1 \mathrm{~b}$ & 1.081 & 6.220 & 0.00 & Yes \\
\hline Brave $\rightarrow$ BATT & $\mathrm{H} 2$ & 0.569 & 4.323 & 0.00 & Yes \\
\hline Brave $\rightarrow$ CBI & $\mathrm{H} 3$ & 0.924 & 6.140 & 0.00 & Yes \\
\hline
\end{tabular}

Table 9: Summary of hypotheses test results with self brand congruity as mediator (study 4)

\begin{tabular}{ccclccc}
\hline $\begin{array}{c}\text { Hypothesi } \\
\mathbf{s}\end{array}$ & $\begin{array}{c}\text { Dependen } \\
\mathbf{t} \text { variable }\end{array}$ & $\begin{array}{c}\text { Independent } \\
\text { variable }\end{array}$ & Direct effect & $\begin{array}{c}\text { Indirect } \\
\text { effect }\end{array}$ & $\begin{array}{c}\text { Type of } \\
\text { mediation }\end{array}$ & $\begin{array}{c}\text { Hypothesis } \\
\text { supported }\end{array}$ \\
\hline $\mathbf{H 4}$ & $\begin{array}{c}\text { Brand } \\
\text { bravery } \\
\text { Brand } \\
\text { bravery }\end{array}$ & $\begin{array}{c}\text { Brand } \\
\text { attitude } \\
\text { consumer } \\
\text { brand } \\
\text { identification }\end{array}$ & $\beta=0.321^{*}$ & $\beta=0.140^{*}$ & Partial & Yes \\
& \multicolumn{2}{c}{$\begin{array}{l}\text { Partial } \\
\text { Note: }{ }^{* *} p<0.05 ; * p<0.01\end{array}$} & Yes \\
\hline
\end{tabular}


Figure 1: Second order reflective model of perceived brand bravery

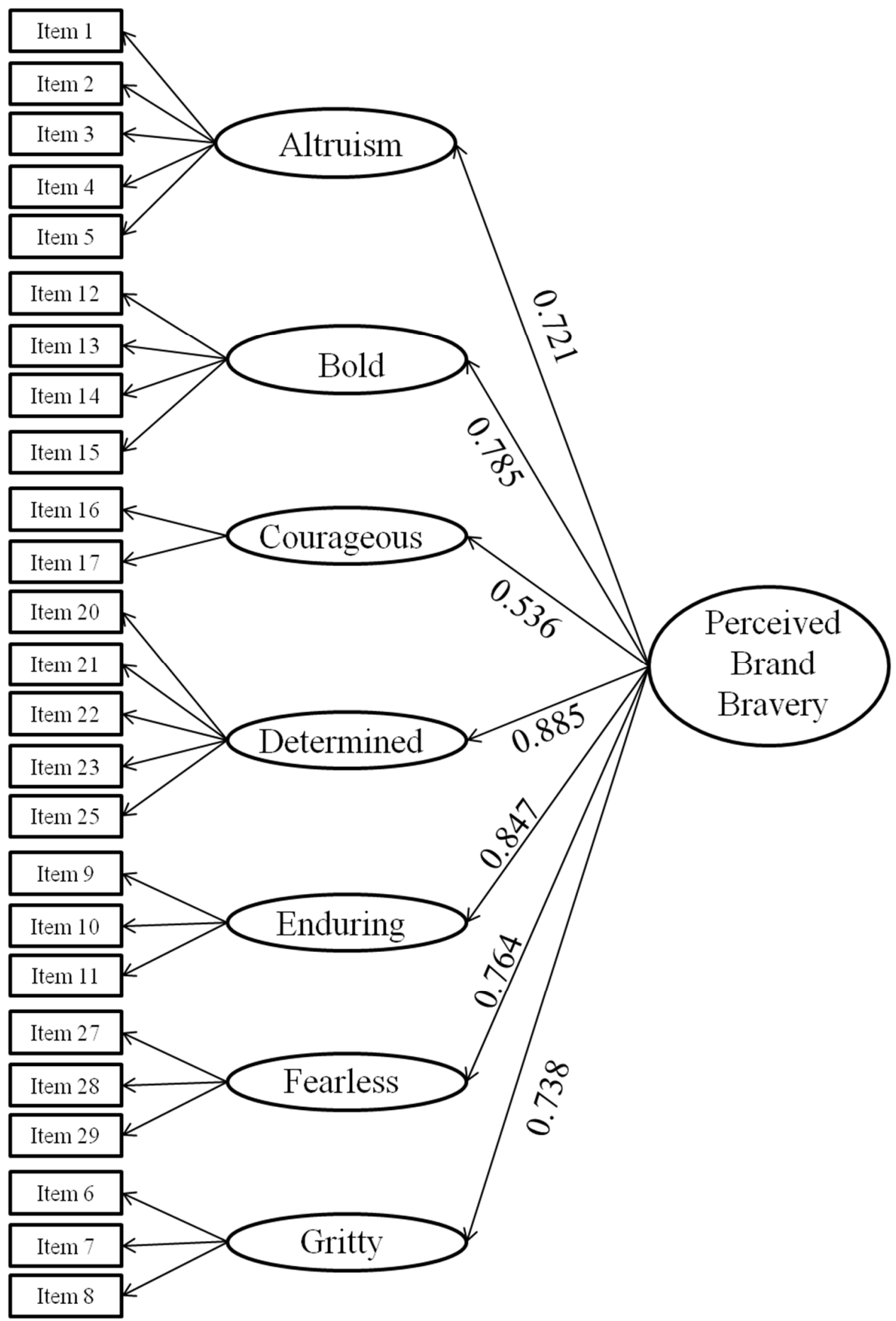


Figure 2: Scale development summary

\section{Phase 1 - Item generation, content and face validity}

- Item generation: An initial pool of 50 items is generated and categorized under six dimensions according to the themes identified in qualitative study 1 . The dimensions are named as -ABCDEF (Altruism, Bold,

Confident, Determined, Enduring, Fearless)

- Face and content validity checks led to a 31 item scale with six dimensions

\section{Phase 2 - Item refinement, dimensionality and reliability}

$-\mathrm{N}=238$ respondents participate in the survey and rate the 31 -items of brand bravery from phase 1

-EFA reveals a 24 item, seven factor matrix. A new dimension is added and the earlier identified themes are now renamed as 7 dimensions of brand bravery: ABCDEFG (Altruism, Bold, Courageous, Determined,

Enduring, Fearless and Gritty)

- CFA confirms a seven factor model with brand bravery as a second order reflective construct

- Convergent validity is established

\section{Phase 3 - Discriminant validity}

- Another survey is conducted with $\mathrm{N}=280$ participants to test the discriminant validity of higher order brand bravery construct with other theoretically distinct but related concepts such as brand integrity, credibility and brand trustworthiness.

- Discriminant validity is established using chi square difference test and Fornell-Larcker criterion

\section{Figure 3: Nomological framework}

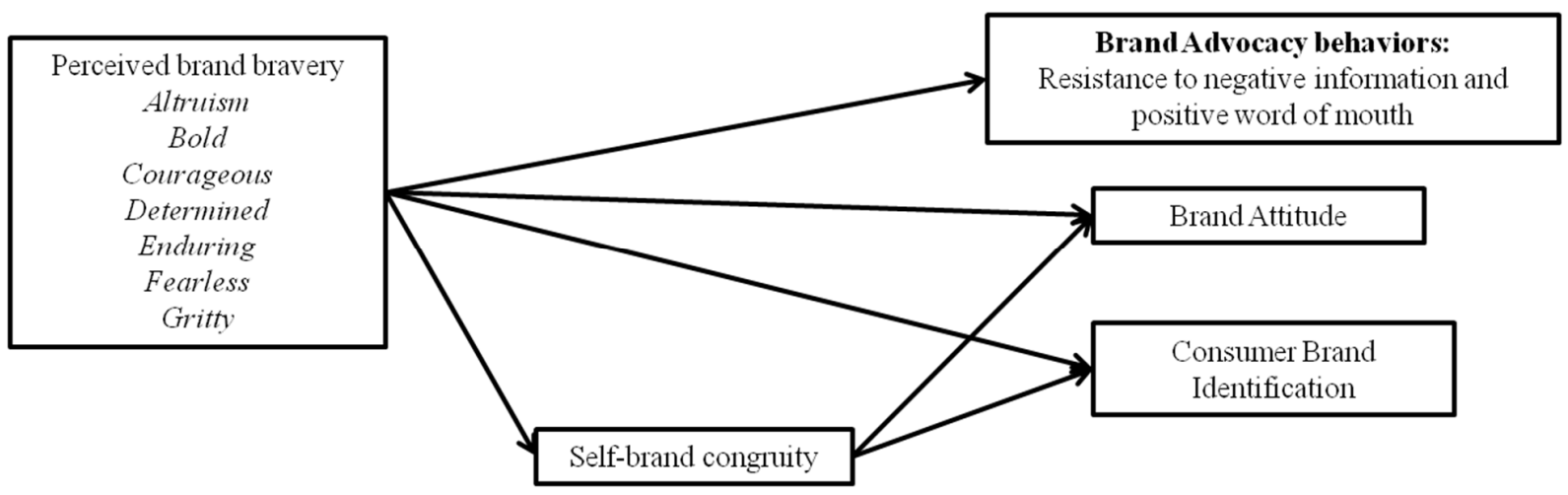


Appendix A: Initial 31 items, 6 factor scale for brand bravery

\begin{tabular}{|c|c|}
\hline $\begin{array}{l}\text { Sub } \\
\text { Dimensions }\end{array}$ & Statements \\
\hline \multirow[t]{5}{*}{ Altruism } & The Brand believes in the greater good \\
\hline & The Brand goes above and beyond its own interest to benefit others \\
\hline & This Brand is not afraid to adapt its strategies if it benefits the society at large \\
\hline & This Brand is willing to reinvent itself for a cause \\
\hline & The Brand is socially responsible and employs sustainable business practices \\
\hline \multirow[t]{5}{*}{ Bold } & The Brand is rebellious \\
\hline & The Brand is innovative and defies the industry norms \\
\hline & The Brand is revolutionary and questions the existing stereotypes \\
\hline & The Brand is unique and stands out of the crowd \\
\hline & The Brand challenges the status quo \\
\hline \multirow[t]{7}{*}{ Confident } & The Brand is not afraid to declare its flaws \\
\hline & The Brand is true to itself \\
\hline & The Brand has a path distinct from its competitors \\
\hline & The Brand acknowledges its constraints \\
\hline & The Brand concedes its mistakes \\
\hline & The Brand challenges itself \\
\hline & The Brand stands up to its competitors \\
\hline \multirow[t]{4}{*}{ Determined } & The brand is strong willed and stands up for what it believes \\
\hline & $\begin{array}{l}\text { The brand is unyielding and sticks to its ground even if doing so may cost its } \\
\text { business }\end{array}$ \\
\hline & The brand is resolute and holds on to its values \\
\hline & The brand remains relentless and refuses to succumb to external power \\
\hline \multirow[t]{5}{*}{ Endurance } & The spirit of the Brand remains unshaken despite failures \\
\hline & The Brand has the strength to overcome dismissals / rejection \\
\hline & The Brand has the mettle to sustain adversities \\
\hline & The Brand has a never-say-die vision \\
\hline & $\begin{array}{l}\text { The Brand possesses the will to evolve continually and stay desirable and } \\
\text { relevant }\end{array}$ \\
\hline \multirow[t]{5}{*}{ Fearlessness } & The Brand is fearless in venturing into new territories \\
\hline & The Brand defines new frontiers in business \\
\hline & The Brand is courageous in taking chances / risks \\
\hline & The Brand has firm resolve to succeed \\
\hline & The Brand stays solid and remains unaffected by criticism \\
\hline
\end{tabular}




\section{Appendix B: illustrations of Human Bravery shortlisted from study 1}

Definition of Brave (as per Oxford English Dictionary): willing to do things that are difficult, dangerous, or painful; not being afraid, showing courage, not giving up etc.

1) Neerja Bhanot: An Indian head purser for the airline who died while saving passengers on Pan Am Flight 73 which had been hijacked by terrorists during a stopover in Karachi, Pakistan, on 5 September 1986.

2) Nelson Mandela (1918 - 2013) had the courage to fight against the unjust system of apartheid. For his political activities, he was sentenced to 20 years in prison, but he was released to lead a free South Africa.

3) Mahatma Gandhi. (1869 - 1948) was the leader of the non-violent movement for Indian independence. Gandhi led the influential Salt Tax protest and was jailed several times for his protests against British rule.

4) Mother Teresa (1910 - 1997) Born in Albania, Mother Teresa left for India with virtually no money and devoted her life to serving the poor of Calcutta - overcoming poverty, disease and criticism. She expanded her mission to support the poor and disadvantaged across the world.

5) Yuvraj Singh bravely fought cancer and returned to the field as he made his comeback in a T20 International against New Zealand in September 2012. 


\section{Appendix C: Scale Items used in study 4}

\section{1) Resistance to Negative Information}

- Negative information about this brand does not change my general view of the firm

- I readily change my view of this brand based on negative information about it

- Negative information about this brand has no effect on me

- Negative information about this brand changes the way I think of the firm

\section{2) Positive Word--of-mouth}

- I recommend to other people to support this brand

- I talk directly to other people about my experience with this brand

- I suggest to others that they should purchase this brand

\section{3) Brand Attitude}

- $\mathrm{Bad} / \operatorname{good}$

- Dislike very much / like very much

- Unpleasant / pleasant

- Unfavorable / favorable

\section{4) Consumer brand identification}

- This brand represents who I am.

- This brand is part of my sense of who I am.

- This brand helps me express my identity.

- I feel personally connected to this brand

\section{5) Self brand congruity}

- This brand reflects who I would like to be (my ideal self)

- This brand is consistent with how I would like to see myself (my ideal self)

- People who are similar to the person that I would like to be (my ideal self) use this brand 